\title{
STORAGE POTENTIAL OF PEELED CRAMBE FOR OIL QUALITY
}

\author{
Silas da S. Santos ${ }^{1}$, Marco A. M. Biaggioni2 ${ }^{*}$, Iara M. C. Monteiro ${ }^{3}$, Maria M. P. Sartori ${ }^{3}$, \\ Fernando J. B. Brandão ${ }^{4}$
}

${ }^{2 *}$ Corresponding author. Universidade Estadual Paulista - UNESP/ FCA/ Botucatu - SP, Brasil.
E-mail: m.biaggioni@unesp.br| ORCID ID: https://orcid.org/0000-0003-2853-9932

\section{KEYWORDS}

hermetic storage, biofuel, biodiesel, oilseeds.

\begin{abstract}
Peeling of crambe fruits, besides increasing the yield of mechanical oil extraction, can increase its apparent specific mass from about 330 to $700 \mathrm{kgm}^{-3}$, reducing transport and storage operating costs, as well as increasing cake protein content. However, there is no information on the quality of the oil extracted from the stored unpeeled crambe. This study aimed to assess the possible effects of peeling fruits submitted to different storage systems. For nine months, peeled and unpeeled crambe fruits were stored in conventional (permeable) and hermetic packages and water content, fatty acid, and acidity and oil peroxide indices were monitored. The experimental design was a completely randomized design in a $2 \times 2 \times 3$ triple factorial, with three replications. After analysis of variance, the mean data were compared by the Tukey's test, being considered significant when $p<0.05$. The results showed that peeled crambe had better conservation in relation to that unpeeled, mainly when submitted to the hermetic storage system.
\end{abstract}

\section{INTRODUCTION}

The Brazilian energy matrix is characterized by the high share of renewable energy sources in its composition, and the greater integration of biofuels in this model can significantly contribute to reducing dependence on non-renewable sources, such as diesel and gasoline, and also in relation to renewable sources, such as hydroelectric energy.

In this context, crambe is a promising alternative for biodiesel production since its seed can contain more than 42\% of oil (Atabani et al., 2013; Santos et al., 2017). Also, its oil is not edible, not competing directly in the food market, in which soybean is the main oilseed used as raw material for more than $70 \%$ of the biodiesel production (Brasil, 2016), competing for human and animal consumption.

Crambe peel, which remains attached to seeds after harvesting, represents up to $30 \%$ of the total mass of fruits and its removal could circumvent one of the major bottlenecks in the establishment of this production chain, i.e., its low apparent specific mass, which generates high costs of transport and storage. Moreover, crambe peeling operation is an essential factor that optimizes mechanical oil extraction, reducing the amount lost by the peel. Santos (2016) studied the effects of the peeling process on crambe oil extraction and concluded that the total peel removal provided a positive and significant effect on the mechanical extraction in an expeller type press, reaching a maximum yield of oil extraction $(37.38 \%)$ and maximum oil recovery $(89.53 \%)$.

On the other hand, the absence of peel, exposing the product to the adverse conditions of the storage environment, with possible impairment of its storage potential, should be considered. Silva et al. (2016a, 2016b) assessed seed quality and pigmentation in the peel and oil of crambe fruits and concluded that post-harvest procedures are essential in defining the final characteristics of seed and oil, which presented significant variations in their viability and final staining as a function of the used drying method.

In this sense, crambe quality during storage, as well as the oil extracted from it, can be assessed from the monitoring of indices such as the levels of free fatty acids and peroxides, which can indicate the deteriorating process still in its initial stages (Silva et al., 2013). The assessment of the oil acidity index, in turn, is very important in deciding which route should be followed during the transesterification and deciding which reaction will be used (the basic or acid) or if it is necessary to subject the oil to a preliminary treatment to reduce oil acidity values (Santos \& Fraga, 2014).

\footnotetext{
${ }^{1}$ FATEC/ Botucatu - SP, Brasil.

${ }^{3}$ Universidade Estadual Paulista - UNESP/FCA/ Botucatu - SP, Brasil.

${ }^{4}$ Instituto Federal do Mato Grosso/ Diamantino - MT, Brasil.

Received in: 9-11-2017

Accepted in: 1-22-2019
} 
The storage of unpeeled crambe has been the main focus among researchers investigating different packages, environments, and storage times. Oliveira et al. (2016), studying the process of degradation of reserves during the germination of crambe seeds, found a linear decrease of lipids, which presented a higher quantity when compared to sugars and starch. However, there is no information on the quality of oil extracted from stored unpeeled grains.

Similarly, Bezerra et al. (2015) observed that quality analyses carried out on the crude oil from stored unpeeled crambe indicate that the iodine and acidity indices presented significantly better mean values in a hermetic bag, demonstrating better efficiency in the maintenance of raw material for biodiesel production. The hermetic package was also able to withstand the influences of environmental conditions, providing higher hygroscopic stability to grains, while the conventional bag was more susceptible to environmental variations during storage, leading toa greater product exposure and reduction in oil quality.

Bessa et al. (2015) comparedpackages and environments along with the storage, assessed water content and electrical conductivity, and concluded that unpeeled crambe seeds stored in hermetic packages in a natural environment presented low electrolyte leaching and better conservation, maintaining their physiological quality for up to six months of storage.
Considering the limited information available on the storage potential of peeled crambe, this study aimed to assess the effects of the peeling process of fruits as a function of different types of packages and storage times.

\section{MATERIAL AND METHODS}

This study was developed at the São Paulo State University - UNESP, School of Agriculture- FCA, campus of Botucatu, located in Botucatu, SP, at the geographical coordinates $22^{\circ} 52^{\prime} 20^{\prime \prime} \mathrm{S}$ and $48^{\circ} 26^{\prime} 37^{\prime \prime} \mathrm{W}$, with a mean altitude of 770 meters, slope of $4.5 \%$, and subtropical climate with warm and humid summers and cold and dry winters.

Crambe fruits were harvested from a production field after drying in the plant and submitted to two treatments: manual peeling $(0 \%$ peel $)$, by fruit friction on a rough surface, and unpeeled (100\% peel - control).

Manual peeling was carried out using three sieves with different meshes. Initially, a sieve (a) with a $2 \mathrm{~mm}$ mesh was used, where fruit mass was placed and the exfoliation process was carried out by compression and friction, leading the peel to separate from the grain. Figure 1 shows the crambe peeling sequence. Peel separation was performed shaking the sieves.

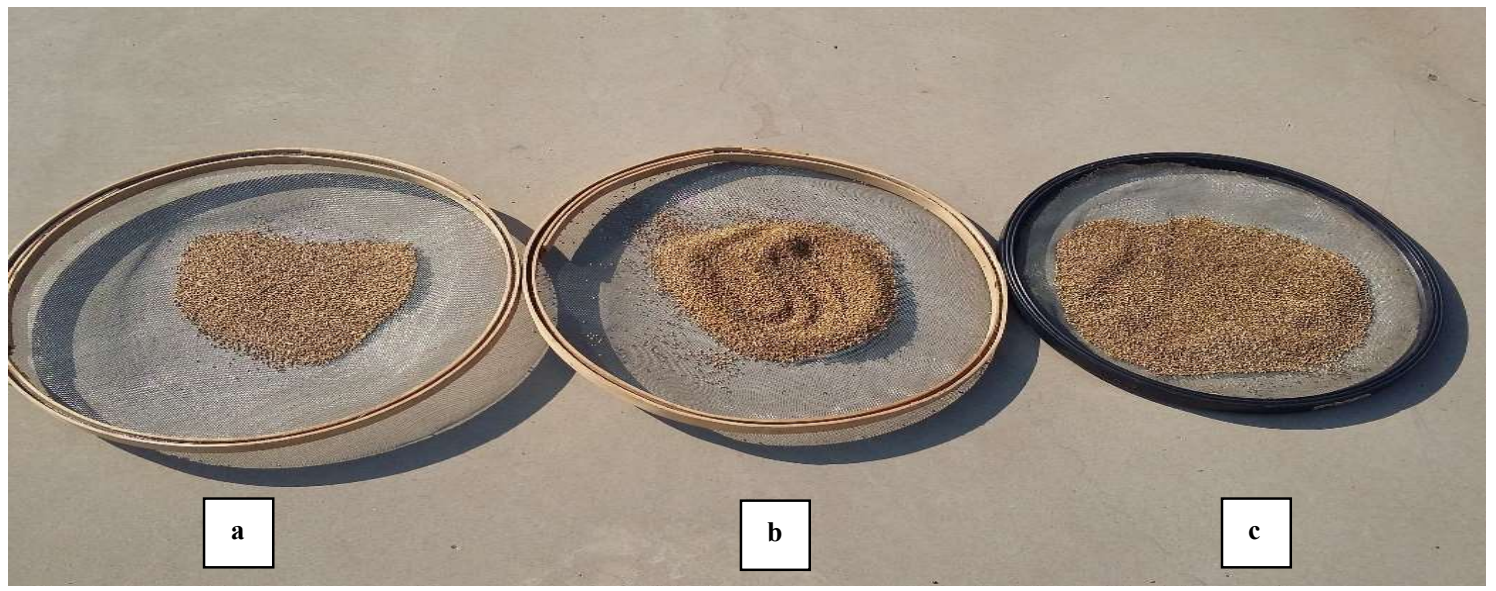

FIGURE 1. Manual peeling process of crambe fruits.

The second sieve (b), with a $1.5 \mathrm{~mm}$ mesh, received all the crambe parts and the whole crambe were separated from peels by a shaking process. The third sieve (c), with a $1 \mathrm{~mm}$ mesh, received the peels along with crambe pieces, and the broken grains were separated from peels. Figure 2 shows the unpeeled and peeled crambe and peels.

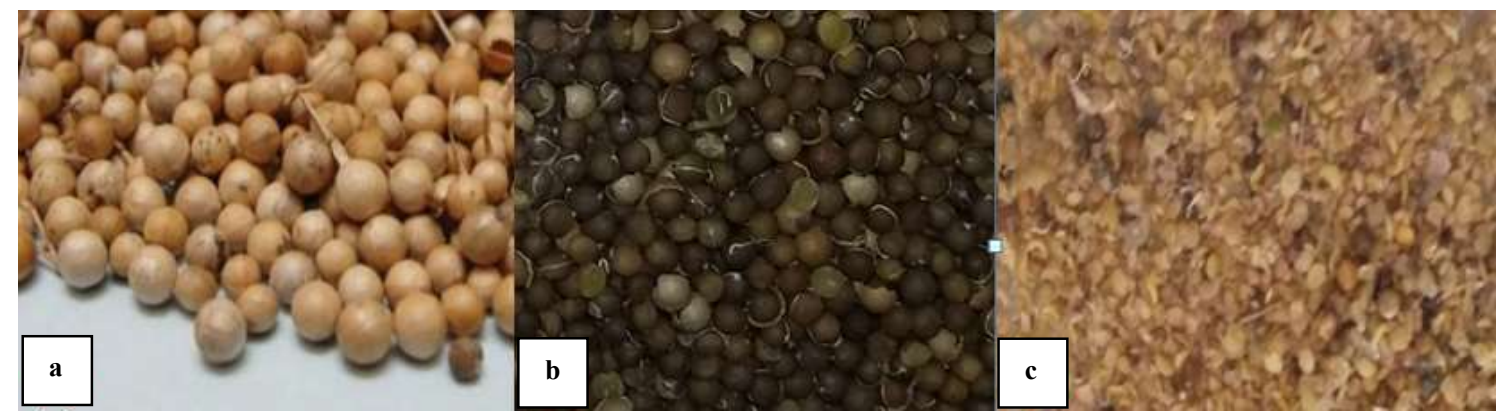

FIGURE 2. Unpeeled (a) and peeled crambe fruits (b) and peels (c) obtained during processing. 
Unpeeled (control) and peeled crambe fruits were stored for nine months and subjected to assessments of product and crude oil quality, performed at the beginning of the storage period (time zero), six months, and end of the storage period.

In order to investigate the impacts of different storage conditions on the quality of crambe fruits and oil extracted from peeled and unpeeled samples, the product was stored in two types of packages: silo-bag (hermetic storage) and kraft paper bag (conventional storage), both with a 5.0 kgcapacity.

Silo-bag consists of an impermeable package with total obstruction to the light passage (black face), avoiding fungus proliferation, and light reflection (white face), causing lower heating of the surface of the stored product.

During the storage period, both silo and paper bags were kept in the natural environment of a laboratory, with daily temperature and relative humidity monitoring. In addition to water content, crambe quality was monitored based on fatty acid analyses performed according to Silva et al. (2016b). Tests of acidity and peroxide indices were performed in the crude oil extracted from crambe fruits, as described by Santos (2016).
The experimental design was a completely randomized design with two types of packages, two peeling conditions, and three storage periods, consisting of a triple factorial $(2 \times 2 \times 3)$ represented by the factors $F 1$ peel (peeled and unpeeled), F2 -package (conventional and hermetic), and F3 -time (T0, T6, and T9), with three replications, totaling 12 treatments and 36 plots.

\section{RESULTS AND DISCUSSION}

Table 1 shows the mean values of water content (wb) of crambe recorded during the storage period in both tested packages. Throughout the monitored period and for all the packages, the peeled crambe remained with a lower water content when compared to the unpeeled crambe, with values varying from 4.76 to $7.22 \%$, while peeled crambe showed values between 7.78 and $9.62 \%$. This behavior can be explained by the higher content of a polar molecules (lipids) in the peeled crambe, conferring a lower water retention capacity than that of the unpeeled crambe since peels allow higher water retention capacity due to the higher content of polar molecules (carbohydrates).

TABLE 1. Mean values of water content (wb) of peeled and unpeeled crambe stored for nine months in conventional and hermetic packages.

\begin{tabular}{ccccccc}
\hline \multicolumn{9}{c}{ Water content $(\mathbf{w b})$} \\
\hline Peel & Conventional & \multicolumn{3}{c}{ Hermetic } \\
T0 & T6 & T9 & T0 & T6 & T9 \\
WITH & 8.92 & 7.91 & 7.78 & 8.92 & 9.13 & 9.62 \\
\hline WITHOUT & 7.22 & 5.62 & 5.60 & 7.22 & 4.76 & 4.84 \\
\hline
\end{tabular}

Similar behavior was observed in peeled and unpeeled crambe fruits in both hermetic and conventional packages regarding the effect of time on water content from the sixth month of storage, which led to a low drying in the stored crambe. However, the treatment with unpeeled crambe stored in hermetic packages showed an increase in water content in the sixth and ninth month. Variations of humidity in conventional packages may be related to exchanges with the external environment, allowed by paper bags, with a mean reduction in the relative air humidity of $80.1 \%$ in the first six months to $72.5 \%$ in the last three months. For hermetic packages, variations may have occurred due to a tendency of the water to be redistributed in the stored mass over time due to an unevenness in the product moisture at the beginning of storage.

Masetto et al. (2013) also found a variation in water content (6.5 to $10.2 \%)$ of stored crambe, regardless of packages and environmental conditions. According to them, the package bag (hermetic) was able to withstand environmental influences until the sixth month of storage, recording a significant increase in water content of crambe fruits after 12 months. The conventional package allowed a significant rewetting in crambe fruits stored from the sixth month, showing unsafe levels for its conservation at the end of 12 months. The hermetic package also provided the maintenance of seed vigor, guaranteeing efficiency in the conservation for a period of up to 180 days of storage.

\section{Fatty acidity of crambe}

Tables 2 and 3 show the mean values of fatty acid $\left(\mathrm{mL} \mathrm{KOH} 100 \mathrm{~g}^{-1} \mathrm{DM}\right)$ and the slicing of the triple interaction $(\mathrm{P} \leq 0.01)$ between the factors presence of peels (F1), package type (F2), and storage time (F3). 
TABLE 2. Mean values of fatty acidity ( $\left.\mathrm{mL} \mathrm{KOH} 100 \mathrm{~g}^{-1} \mathrm{DM}\right)$ of unpeeled crambe grains stored for nine months in conventional and hermetic packages.

\begin{tabular}{ccccccc}
\hline \multicolumn{8}{c}{$* *$ Fatty acidity $\left(\mathbf{m L}\right.$ KOH $\left.\mathbf{1 0 0} \mathbf{~ g}^{-1} \mathbf{D M}\right)$} \\
\hline Peel & \multicolumn{3}{c}{ Conventional } \\
T0 & T6 & T9 & T0 & T6 & T9 \\
WITH & $6.78 \mathrm{a}$ & $8.44 \mathrm{a}$ & $7.44 \mathrm{~b}$ & $6.78 \mathrm{a}$ & $8.97 \mathrm{a}$ & $9.22 \mathrm{a}$ \\
\hline WITHOUT & $7.42 \mathrm{a}$ & $7.37 \mathrm{~b}$ & $8.65 \mathrm{a}$ & $7.42 \mathrm{a}$ & $6.61 \mathrm{~b}$ & $6.74 \mathrm{~b}$ \\
\hline
\end{tabular}

**Significant at $1 \%$ probability level $(\mathrm{p}<0.01)$. Means followed by the same letter in the columns do not differ from each other by the Tukey's test at $5 \%$ probability level. $\mathrm{CV}=7.58 \%$.

An alternation was observed in the behavior of peeled and unpeeled crambe fruits regarding fatty acidity level over storage time and package type (Table 2).

At the end of the storage time, the unpeeled crambe was better conserved when compared to that peeled when conventionally stored. On the other hand, peeled crambe presented the lowest free fatty acid level throughout the storage period under the hermetic environment.

This performance can be explained by the protective role of the peel, which provides better protection to the product in a more exposed environment (conventional storage). In the hermetic environment, the lower metabolic activity of crambe fruits as a function of the limited gas exchanges with the external environment guaranteed the necessary protection to the peeled product.
A differential behavior was observed between peeled and unpeeled crambe fruits regarding the storage time. There is a deterioration trend (significant increase of free fatty acids) of the unpeeled crambe from the sixth month of storage when packaged both conventionally and hermetically (Table 3). On the other hand, the peeled crambe showed deterioration effects only in the ninth month of storage in conventional packages, but these effects were not detected using hermetic packages.

These results were similar to those found by Bezerra et al. (2015), who observed that bag packages (conventional) were inefficient at six months of storage of unpeeled crambe, as well as the worst result at 12 months of storage, with high contents of fatty acids. However, the hermetic bag presented means of fatty acidity statistically equal at the end of 12 months of storage.

TABLE 3. Mean values of fatty acidity $\left(\mathrm{mL} \mathrm{KOH} 100 \mathrm{~g}^{-1} \mathrm{DM}\right)$ of peeled and unpeeled crambe as a function of storage period and type of package (conventional and hermetic).

\begin{tabular}{cccc}
\hline \multicolumn{5}{c}{$* *$ Fatty acidity $\left(\mathbf{m L}\right.$ KOH $\left.\mathbf{1 0 0} \mathbf{~ g}^{-\mathbf{1}} \mathbf{D M}\right)$} \\
\hline \multirow{2}{*}{ Peel } & Time (months) & Conventional & Hermetic \\
\hline \multirow{2}{*}{ WITH } & T0 & $6.78 \mathrm{Ab}$ & $6.78 \mathrm{Ab}$ \\
& T6 & $8.44 \mathrm{Aa}$ & $8.97 \mathrm{Aa}$ \\
& T9 & $7.44 \mathrm{Bab}$ & $9.22 \mathrm{Aa}$ \\
\hline \multirow{2}{*}{ WITHOUT } & T0 & $7.42 \mathrm{Ab}$ & $7.42 \mathrm{Aa}$ \\
& T6 & $7.37 \mathrm{Ab}$ & $6.61 \mathrm{Aa}$ \\
& T9 & $8.65 \mathrm{Aa}$ & $6.74 \mathrm{Ba}$ \\
\hline
\end{tabular}

**Significant at $1 \%$ probability level $(\mathrm{p}<0.01)$. Means followed by the same uppercase letter in the rows and lowercase letter in the columns for each factor (peeled and unpeeled) do not differ from each other by the Tukey's test at 5\% probability level. CV $=7.58 \%$.

\section{Oil acidity index}

Tables 4 and 5 show the mean values of the crude oil acidity index $\left(\mathrm{mg} \mathrm{KOH} 100 \mathrm{~g}^{-1}\right)$ extracted from crambe grains and the slicing of the triple interaction between the factors presence of peel (F1), package type (F2), and storage time (F3).

TABLE 4. Mean values of the crude oil acidity index $\left(\mathrm{mg} \mathrm{KOH} 100 \mathrm{~g}^{-1}\right)$ extracted from peeled and unpeeled crambe grains stored for nine months in conventional and hermetic packages.

\begin{tabular}{ccccccc}
\hline \multicolumn{9}{c}{ ** Oil Acidity Index $\left(\mathbf{m g ~ K O H ~}^{-1}\right)$} \\
\hline Peel & \multicolumn{3}{c}{ Conventional } & \multicolumn{3}{c}{ Hermetic } \\
T0 & T6 & T9 & T0 & T6 & T9 \\
WITH & $0.25 \mathrm{a}$ & $1.21 \mathrm{a}$ & $1.30 \mathrm{a}$ & $0.25 \mathrm{a}$ & $1.30 \mathrm{a}$ & $1.22 \mathrm{a}$ \\
WITHOUT & $0.19 \mathrm{a}$ & $1.15 \mathrm{a}$ & $1.22 \mathrm{a}$ & $0.19 \mathrm{a}$ & $0.92 \mathrm{~b}$ & $1.18 \mathrm{a}$ \\
\hline
\end{tabular}

**Significant at $1 \%$ probability level $(\mathrm{p}<0.01)$. Means followed by the same letter in the columns do not differ from each other by the Tukey's test at $5 \%$ probability level. $\mathrm{CV}=5.93 \%$. 
Although a significant difference occurred only in the sixth month of storage in hermetic packages, there is a tendency of the peeled crambe to present lower oil acidity when compared to that unpeeled over the storage time and for any package (Table 4).

Table 5 shows a similar behavior between peeled and unpeeled material, regardless of the type of package regarding the storage time. The effect of deterioration (significant increase of oil acidity) was verified from the sixth month of storage. At this point, the oil acidity index showed to be a more rigorous test than that fatty acidity, with a significant deterioration for all treatments from the sixth month of storage.

These results are in accordance with the information obtained in the fatty acidity tests. The hermetic package provided the development of lower oil acidity indices and hence lower deterioration for the peeled crambe.

TABLE 5. Mean values of the crude oil acidity index $\left(\mathrm{mg} \mathrm{KOH} \mathrm{g}^{-1}\right)$ extracted from peeled and unpeeled crambe as a function of storage period and type of package (conventional and hermetic).

\begin{tabular}{|c|c|c|c|}
\hline \multicolumn{4}{|c|}{$* *$ Oil acidity index $\left(\mathrm{mg} \mathrm{KOH} \mathrm{g^{-1 } )}\right.$} \\
\hline \multirow[b]{2}{*}{ Peel } & \multirow[b]{2}{*}{ Time (months) } & \multicolumn{2}{|c|}{ Package } \\
\hline & & Conventional & Hermetic \\
\hline \multirow{3}{*}{ WITH } & T0 & $0.25 \mathrm{Ab}$ & $0.25 \mathrm{Ab}$ \\
\hline & T6 & $1.21 \mathrm{Ba}$ & $1.30 \mathrm{Aa}$ \\
\hline & T9 & $1.30 \mathrm{Aa}$ & $1.22 \mathrm{Aa}$ \\
\hline \multirow{3}{*}{ WITHOUT } & T0 & $0.19 \mathrm{Ab}$ & $0.19 \mathrm{Ac}$ \\
\hline & T6 & $1.15 \mathrm{Aa}$ & $0.92 \mathrm{Bb}$ \\
\hline & T9 & $1.22 \mathrm{Aa}$ & $1.18 \mathrm{Aa}$ \\
\hline
\end{tabular}

**Significant at $1 \%$ probability level $(\mathrm{p}<0.01)$. Means followed by the same uppercase letter in the rows and lowercase letter in the columns for each factor (peeled and unpeeled) do not differ from each other by the Tukey's test at $5 \%$ probability level. $\mathrm{CV}=5.93 \%$.

The mean values of oil acidity indices of crambe are close to those obtained by Silva et al. (2013), who studied the quality of crude oil of crambe at different drying types and found values of oil acidity index of $0.43 \mathrm{mg} \mathrm{KOH} \mathrm{g}^{-1}$ of sample for the unpeeled crambe.

\section{Oil peroxide index}

Tables 6 and 7 show the mean values of the crude oil peroxide index (meq $\mathrm{O}_{2} \mathrm{~kg}^{-1}$ ) extracted from crambe and the slicing of double interactions $(\mathrm{P} \leq 0.01)$ between the factors presence of peel (F1), package type (F2), and storage time (F3).

TABLE 6. Mean values of the crude oil peroxide index $\left(\mathrm{meqO} \mathrm{kg}^{-1}\right)$ extracted from peeled and unpeeled crambe stored for nine months and obtained from the slicing of the interaction between the factors F1 and F3.

\begin{tabular}{cccr}
\hline & $* *$ Oil peroxide index $\left(\mathbf{m e q} \mathbf{O}_{\mathbf{2}} \mathbf{k g}^{-\mathbf{1}}\right)$ & \\
\hline Peel & T0 & T6 & T9 \\
\hline WITH & 0.00 a C & 3.49 a B & 5.00 a A \\
WITHOUT & 0.00 a B & 3.17 b A & 3.14 b A \\
\hline
\end{tabular}

**Significant at $1 \%$ probability level $(\mathrm{p}<0.01)$. Means followed by the same uppercase letter in the rows and lowercase letter in the columns do not differ from each other by the Tukey's test at 5\% probability level. CV $=7.26 \%$.

Table 6 shows that the double interaction was significant between F1 and F3 and that the peeled crambe stored had a trend to provide the lowest peroxide indices, suggesting that the best way to store crambe would be peeled.

TABLE 7. Mean values of the crude oil peroxide index $\left(\mathrm{meqO}_{2} \mathrm{~kg}^{-1}\right)$ extracted from crambe stored for nine months in conventional and hermetic packages and obtained from the slicing of the interaction between the factors F2 and F3.

\begin{tabular}{cccc}
\hline & $* *$ Crambe peroxide index $\left(\mathbf{m e q} \mathbf{O}_{\mathbf{2}} \mathbf{~ k g}^{-\mathbf{1}}\right)$ & \\
\hline Package & T0 & T6 & T9 \\
\hline Conventional & $0.00 \mathrm{aC}$ & $3.34 \mathrm{aB}$ & $5.39 \mathrm{aA}$ \\
Hermetic & $0.00 \mathrm{aB}$ & $3.32 \mathrm{aA}$ & $2.74 \mathrm{bB}$ \\
\hline
\end{tabular}

**Significant at $1 \%$ probability level $(\mathrm{p}<0.01)$. Means followed by the same uppercase letter in the rows and lowercase letter in the columns do not differ from each other by the Tukey's test at $5 \%$ probability level. $\mathrm{CV}=7.26 \%$. 
Table 7 shows that the double interaction was significant between F2 and F3 and that the product stored in a hermetic package had a trend to provide the lowest quality losses, with lower peroxide indices. Probably, the lower oxygen content in these packages contributed to reducing the oxidation reactions of lipids in crambe fruits. These values indicate low oxidative rancidity and good stability of crambe oil.

Tables 6 and 7 also show the same trend for storage time, i.e., deteriorations are significant from the sixth month, with more pronounced effects over time in unpeeled products and conventional packages. According to Donadon et al. (2015), the peroxide index is influenced by environment and storage time, with a linear increase as a function of time, indicating degradation and oxidation of the oil.

The unexplained decrease in the peroxide index of crambe hermetically packaged in the ninth month (Table 7), when compared to the sixth month of storage, may be due to the transitory character of peroxide production, which may have its rate of formation during oxidation exceeded by the speed of use in secondary reactions.

The values of peroxide index found in this study are close to those obtained by Silva et al. (2013), who studied the quality of crude oil of crambe at different drying types and found mean values of peroxide index close to 2.74 meq $\mathrm{O}_{2} \mathrm{~kg}^{-1}$ for crambe dried in the plant.

\section{CONCLUSIONS}

The results obtained in this study allowed the following main conclusions:

- The peroxide index pointed out to a better crambe preservation when stored without peeling and in a hermetic package.

- Fatty acidity test and the oil acidity index were more sensitive and indicated a better peeled crambe preservation when stored hermetically, while the unpeeled product showed less deterioration in the conventional storage.

- Significant quality losses of the stored crambe were detected from the sixth month of storage but delayed from the ninth month when in a hermetic package.

\section{REFERENCES}

Atabani AE, Silitongaa AS, Onga HC, Mahiac TMI, Masjuki HH, Badruddina IA, Fayaz H (2013) Non-edible vegetable oils: A critical evaluation of oil extraction, fatty acid compositions, biodiesel production, characteristics, engine performance and emissions production. Renewable and Sustainable Energy Reviews 18:211-245.

Bessa JFV, Donadon JR, Resende O, Alves RMV, Sales J de F, Costa LM (2015) Armazenamento do crambe em diferentes embalagens e ambientes: Parte I - Qualidade fisiológica. Revista Brasileira de Engenharia Agrícola Ambiental 19(3):224-230.

Bezerra PHS, Biaggioni MAM, Silva MAP, Sperotto FCS, Brandão FJB (2015) Efeito do armazenamento na qualidade dos grãos e do óleo de crambe para produção de biodiesel. Energia na Agricultura 30(3):310-318.
BRASIL (2016) Agência Nacional do Petróleo, Gás Natural e Biocombustíveis. Boletim mensal do biodiesel. Rio de Janeiro. Available:

http://www.anp.gov.br/wwwanp/images//publicacoes/bolet insanp/Boletim_Mensal_do_Biodiesel/Boletim_Biodiesel_ DEZEMBRO_2016.pdf. Accessed: Jan 15, 2017.

Donadon JR, Bessa JFV, Resende O, Castro CFS, Alves RMV, Silveira EV (2015) Armazenamento do Crambe em diferentes embalagens e ambientes: Parte II - Qualidade Química. Revista Brasileira de Engenharia Agrícola e Ambiental 19(3):231-237.

Masetto TE, Gordin CRB, Quadros JB, Rezende RKS, Scalon SPQ (2013) Armazenamento de sementes de Crambe abyssinica Hochst. Ex. R.E.Fr. em diferentes embalagens e ambientes. Revista Ceres 60(5):646-652. Available: http://www.scielo.br/pdf/rceres/v60n5/07.pdf. Accessed: Aug 17, 2016.

Oliveira EF, Reche AM, Silva MAP, Amaro ACE, Biaggioni MAM, Ferreira G (2016) Degradation of reserves of crambe seed (Crambe abyssinica) during germination. African Journal of Agricultural Research 11(11):920-924.

Santos CCA dos, Fraga IM (2014) Influência do índice de acidez do óleo extraído da bacaba (Oenocarpus distichus Mart.), na reação de transesterificação via catálise básica para produção de biodiesel. Revista Química Industrial 1(742). Available: http://www.abq.org.br/rqi/2014/742/RQI72-pagina16-influencia-do-indice-de-acidez-do-oleo-extraidoda-bacaba.pdf. Accessed: Aug 18, 2016.

Santos S da S (2016) Processo de descasque de crambe (Crambe abyssinica Hochst) visando a extração de óleo e armazenamento. Dissertação Mestrado em Agronomia, Botucatu, Universidade Estadual Paulista, Júlio de Mesquita Filho, Faculdade de Ciências Agronômicas.

Santos SS, Biaggioni MAM, Sartori MMP, Monteiro IMC, Souza IF (2017) Processo de descasque de crambe [Crambe hyspanica subesp. abyssinica (Hochst. ex R.E. Fr.) PRINA] visando à extração de óleo. Energia na Agricultura 32:109-116.

Silva MAP, Biaggioni MAM, Sperotto FCS, Bezerra PHS, Brandão FJB (2013) Qualidade do oleo bruto de grãos de crambe (Crambe abyssinica Hochst) sob diferentes métodos de secagem. Energiana Agricultura 28(3):193-199.

Silva MAP, Biaggioni MAM, Sperotto FCS, Macedo AC, Brandão FJB (2016a) Effect of drying methods on crambe (Crambe abyssinica Hochst) seed coat pigmentation and on oil and biodiesel quality. EngenhariaAgrícola 36(6):1167-1175.

Silva MAP, Lima JJP, Biaggioni MAM, Cavariani C, Ferreira G (2016b) Seed quality of crambe (Crambe abyssinica Hochst) submitted to different drying methods. Revista Ciência Agronômica 47(2):358-365. 